\title{
High-Resolution Manometry in the Diagnosis and Classification of Achalasia in Children
}

\author{
Erick Toro-Monjaraz, Rubén Peña-Vélez, María José Carrillo-Quan, David Avelar-Rodríguez, \\ Martha Cecilia Martínez-Soto, Karen Ignorosa-Arellano, Roberto Cervantes-Bustamante, \\ Jaime Ramírez-Mayans
}

Departamento de Gastroenterología Pediátrica y Nutrición, Instituto Nacional de Pediatría. Ciudad de México, México.

Acta Gastroenterol Latinoam 2020;50(1):57-61

Received: 23/05/2018 / Accepted: 18/06/2018 / Published online: 23/03/2020 / https://doi.org/10.52787/ggus4980

\section{Summary}

Esophageal achalasia is a primary motor disorder that presents with dysphagia secondary to esophageal body dysfunction and functional obstruction of the lower esophageal sphincter. High-resolution manometry is considered the gold standard for the diagnosis of achalasia and, according to the Chicago classification v3.0; it can be further divided into three different subtypes based on the pressurization patterns. Herein, we present the case series of 6 pediatric patients in whom high-resolution manometry was performed for the diagnosis and classification of esophageal achalasia.

Keywords. Dysphagia, achalasia, esophageal manometry.

\section{Manometría esofágica de alta resolu- ción en el diagnóstico y clasificación de acalasia en niños}

\section{Resumen}

La acalasia esofágica es un trastorno motor primario que se presenta con disfagia secundaria a la disfunción del cuerpo del esófago y a la obstrucción funcional del esfínter esofágico inferior. La manometría de alta resolución se considera el estándar de oro para el diagnóstico de acalasia, y según la clasificación de Chicago V3.0 puede dividirse en tres subtipos diferenciados por los patrones de presurización. Presentamos una serie de casos de 6 pacientes pediátricos en quienes se realizó manometría esofágica de alta resolución para el diagnóstico y clasificación de acalasia.

Palabras claves. Disfagia, acalasia, manometría esofágica.

\author{
Abbreviations \\ HREM: High-resolution esophageal manometry. \\ EA: Esophageal achalasia. \\ GERD: Gastroesophageal reflux disease. \\ LES: Lower esophageal sphincter.
}

\section{Introduction}

Esophageal Achalasia (EA) is a primary motor disorder of the esophagus, characterized by the progressive decrease of peristalsis and lack of relaxation of the Lower Esophageal Sphincter (LES). EA in pediatrics in uncommon, with an annual incidence of 0.18 cases per 100,000 children. ${ }^{1}$
Correspondence: Rubén Peña-Vélez

Insurgentes Sur 3700, Coyoacán (C.P.: 04300). Ciudad de México,

México / Tel.: 5510840900 (extensión 1884)

Email: rubenpevelez@hotmail.com 
The clinical presentation is diverse and includes vomiting, progressive dysphagia to liquids, caught and weight loss. ${ }^{1,2}$ The diagnostic workup includes contrasting imaging studies, upper endoscopy and High-Resolution Esophageal Manometry (HREM), with the last one being able to classify the different subtypes of EA based on the pressurization pattern and is considered the gold standard. ${ }^{3}$

In this case series, we included pediatric patients who were referred to the Gastroenterology Physiology and Motility Unit at the Instituto Nacional de Pediatría for the evaluation of symptoms suggestive of EA. Also, patients already diagnosed with EA, but in whom classification had not been established were included. All the patients consented to the performance of the HREM. The software and equipment Sandhill Scientific ZVU 2.1 (Highlands Ranch, CO) were used.

We describe the clinical and manometric features of the 6 patients diagnosed with EA based on the Chicago 3.0 classification.

\section{Case series}

Manometric findings are described in Table 1.

\section{Case 1}

6-year-old male with chronic under nutrition (Body Mass Index [BMI]: 12.37, Standard Deviation [SD]: +/- 3.91). He presented with vomiting, caught and progressive dysphagia to liquids. He underwent a barium swallow, which revealed esophageal stenosis at the esophagogastric junction, and showed the "bird beak" sign. Upper endoscopy showed esophageal dilatation in its entirety, as well as a central and punctiform sphincter. HREM was consistent with type II EA (Figure 1). The patient underwent Heller myotomy, but the

Figure 1. HREM plot showing esophageal panpressurization and incomplete relaxation of the LES

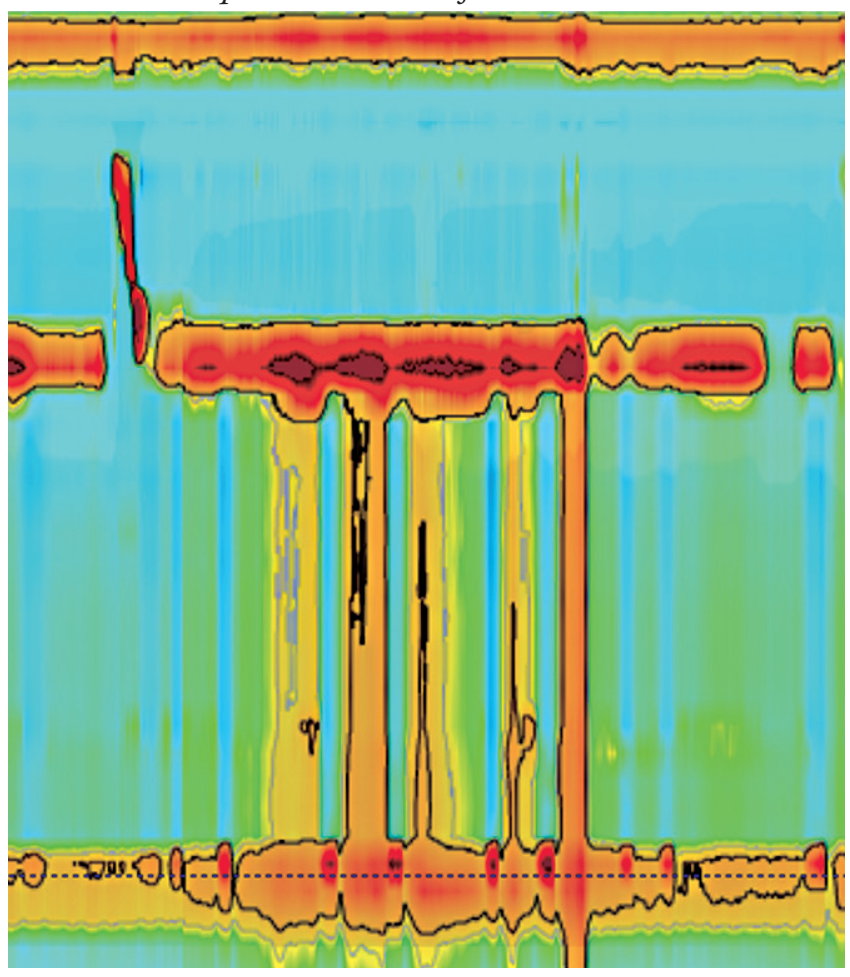

Tabla 1. Manometric findings in pediatric patients with achalasia

\begin{tabular}{|c|c|c|c|c|c|c|c|c|}
\hline Case & $\begin{array}{c}\text { Age } \\
\text { (years) }\end{array}$ & Type & $\begin{array}{c}\mathrm{IRP} \\
(\mathrm{mmHg})\end{array}$ & $\begin{array}{c}\mathrm{DCl} \\
(\mathrm{mmHg} / \mathrm{cm} / \mathrm{s})\end{array}$ & $\begin{array}{c}\text { LES } \\
\text { pressure }\end{array}$ & $\begin{array}{l}\text { LES } \\
\text { length }\end{array}$ & GEJ & Peristalsis \\
\hline 1 & 6 & $\|$ & 34 & 60 & 21 & 2.3 & 1 & $\begin{array}{l}\text { Panesophagea } \\
\text { pressurization }\end{array}$ \\
\hline 2 & 2 & $\|$ & 20 & 548 & 26 & 2.1 & 1 & $\begin{array}{l}\text { Panesophagea } \\
\text { pressurization }\end{array}$ \\
\hline 3 & 16 & $\|$ & 20 & 5026 & 50 & 3.8 & 1 & $\begin{array}{l}\text { Panesophagea } \\
\text { pressurization }\end{array}$ \\
\hline 4 & 1 & $\|$ & 28 & 321 & 20 & 2.9 & 1 & $\begin{array}{l}\text { Panesophagea } \\
\text { pressurization }\end{array}$ \\
\hline 5 & 1 & I & 22 & 160 & 49 & 2 & 1 & Aperistalsis \\
\hline 6 & 17 & III & 30 & 10413 & 30 & 2.4 & 1 & Spastic \\
\hline
\end{tabular}


improvement of symptoms was not satisfactory, so he was treated with botulinum toxin (100 IU) showing a good response.

\section{Case 2}

2-year 4-month-old female with chronic under nutrition (BMI: 13.98, SD: +/ 2.35) and a history of global neurodevelopmental delay. At 2 months of age, she began having vomiting and dyschezia, as well as multiple episodes of pneumonia. A diagnosis of Gastroesophageal reflux disease (GERD) was made and she received many medical treatments. Upper endoscopy showed suggestive signs of achalasia, and HREM confirmed the diagnosis of type II EA. She underwent fundoplication and Heller myotomy.

\section{Case 3}

A 16-year-old female with normal weight and height (BMI: 19.34, SD: +/- 0.33). She had a history of progressive dysphagia, vomiting, and nocturnal regurgitation. Upper endoscopy showed esophageal stenosis and barium swallow showed the "bird beak" sign (Figure 2). HREM was consistent with type II EA.

Figure 2. Barium swallows showing tapering of the distal esophagus (the "bird beak" sign)

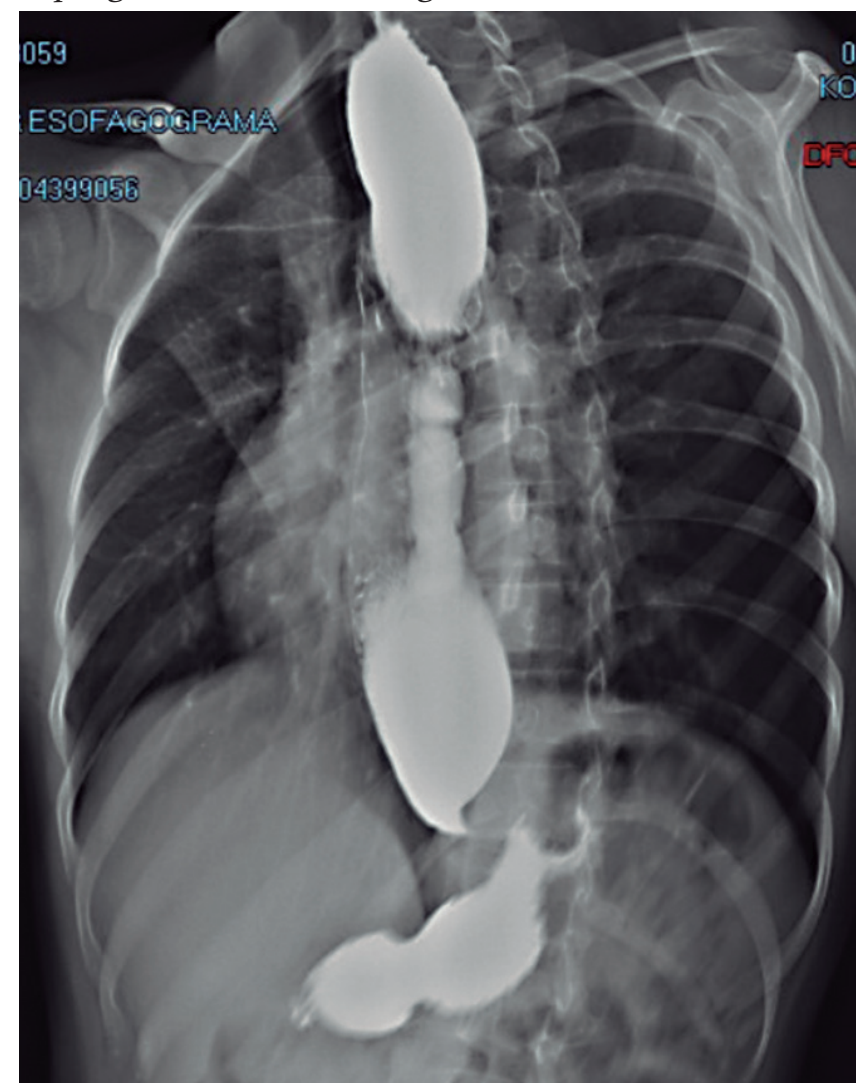

\section{Case 4}

A 1-year-old male with chronic malnutrition (BMI: 13.30, SD: +/-3.05). He was referred to us to perform a follow-up HERM. At 15 days of age, he presented with vomiting, irritability, and constipation. After an exhaustive workup, at 4 months of age, he was diagnosed with EA and was treated with esophageal dilatations, followed by Heller myotomy. HREM was consistent with type II EA.

\section{Case 5}

A 1-year 9-month old female with chronic under nutrition. She had a history of vomiting, dysphagia and poor weight gain. She was referred to us to perform an HREM, which was consistent with type I EA. (Figure 3).

Figure 3. HREM plot showing esophageal aperstialsis and incomplete relaxation of the LES

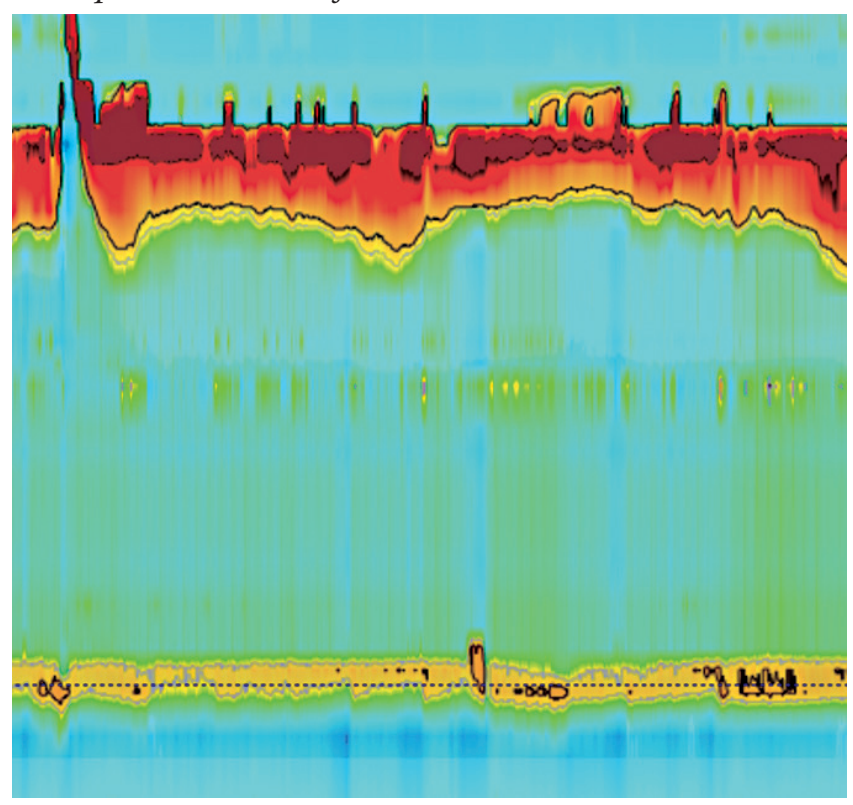

\section{Case 6}

An 18-year-old female with chronic under nutrition. She had a history of common variable immunodeficiency and autoimmune diseases (vitiligo and autoimmune thyroiditis). At 17 years of age, she began complaining of chest pain and rapidly progressive dysphagia; an HREM was performed, which was consistent with type III EA. (Figure 4). 
Figure 4. HREM plot showing spastic esophageal contractions and incomplete relaxation of the LES

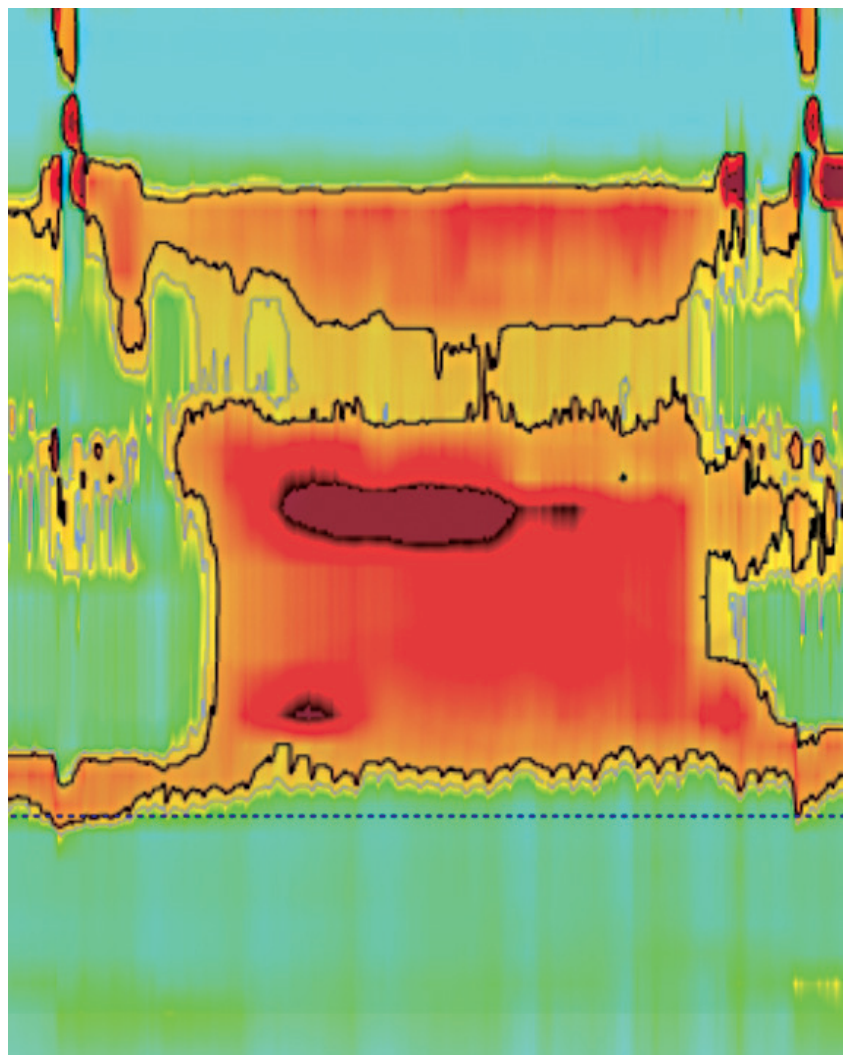

\section{Discussion}

EA is a neurodegenerative disorder with a low incidence in the pediatric population. The most common symptoms in our patients were vomiting, progressive dysphagia to liquids and weight loss, which is concordant with the medical literature. ${ }^{4}$ These symptoms may also be suggestive of GERD and can delay the diagnosis, as in the case of some of our patients. ${ }^{5}$

Barium swallow typically shows the "bird beak" sign, in conjunction with aperistalsis and poor contrast emptying. ${ }^{1}$ Upper endoscopy is not routinely indicated in children, especially if the clinical presentation is evident. ${ }^{3}$ In fact, upper endoscopy and imaging studies were performed in some of our patients as part of the diagnostic workup before performing the HREM.

The introduction of the HREM has improved the characterization of esophageal motor function. ${ }^{6}$ Although clinical and radiological findings can be suggestive of EA, HREM is considered the gold standard for its diagnosis and further classification. ${ }^{7}$

According to the Chicago classification v3.0 (CC), EA can be divided into three different subtypes based on the pressurization patterns. Type I EA (classic) exhibits $100 \%$ failed peristalsis; type II (with esophageal compression) exhibits panpressurizations in at least $20 \%$ of swallows; and type III (spastic) exhibits premature contractions in at least $20 \%$ of swallows ${ }^{7,8}$ (Table 2).

Type II EA is the most common subtype and the one with the most favourable treatment response, followed by type I. ${ }^{9,}{ }^{10}$ On the other hand, type III EA is the least common subtype and the one with the poorest treatment response. In the present study, we found 4 patients with type II EA, 1 patient with type I and 1 adolescent with type III, which is concordant with other cases series of pediatric patients with EA. ${ }^{11}$

Tabla 2. Chicago Classification based HREM subtypes of achalasia

\begin{tabular}{|c|c|c|c|c|c|}
\hline \multirow{2}{*}{ Type } & \multirow{2}{*}{ Description } & \multicolumn{4}{|c|}{ HREM criteria } \\
\hline & & IRP & $\mathrm{DCl}$ & IBP & $\mathrm{DL}$ \\
\hline I & $\begin{array}{c}\text { Classic } \\
\text { achalasia }\end{array}$ & $>15 \mathrm{mmHg}$ & $\begin{array}{c}100 \% \text { failed peristalsis } \\
(=\mathrm{DCl}<100 \mathrm{mmHg} / \mathrm{cm} / \mathrm{s})\end{array}$ & NA & NA \\
\hline$\|$ & $\begin{array}{l}\text { Panesophageal } \\
\text { pressurization }\end{array}$ & $>15 \mathrm{mmHg}$ & $\begin{array}{c}100 \% \text { failed peristalsis } \\
(=\mathrm{DCl}<100 \mathrm{mmHg} / \mathrm{cm} / \mathrm{s})\end{array}$ & $\begin{array}{c}>20 \% \\
\text { panesophageal } \\
\text { pressurization } \\
(=\mathrm{IBP}>30 \mathrm{mmHg})\end{array}$ & NA \\
\hline III & $\begin{array}{c}\text { Spastic } \\
\text { achalasia }\end{array}$ & $>15 \mathrm{mmHg}$ & $\begin{array}{l}\text { DCl of premature } \\
\text { contractions } \\
>450 \mathrm{mmHg}\end{array}$ & NA & $\begin{array}{c}>20 \% \\
\text { premature } \\
\text { contractions } \\
(\mathrm{DL}<4.5 \mathrm{~s})\end{array}$ \\
\hline
\end{tabular}

HREM: High resolution esophageal manometry; IRP: Integrated relaxation pressure; DCI: Distal contractile integral; IBP: Intrabolus pressure; DL: Distal latency; NA: Not applicable. 
HREM is widely used in the adult population, and some studies in children suggest that esophageal motility disorders can be classified using the Chicago V3.0 classification. ${ }^{10}$ The HREM in pediatrics has some limitations, some authors have observed that in children the length of the esophagus could influence some metrics. ${ }^{11}$ However, HREM should be considered as a necessary study in the evaluation of children with dysphagia, vomiting, or characteristic symptoms of esophageal motility disorders.

\section{Conclusions}

HREM is useful for the diagnosis and classification of EA in children. Though it is an invasive procedure, the risk of complications is low; thus, it should be performed in children who present symptoms suggestive of EA. These patients should be referred to specialized centres to make a prompt diagnosis and initiate treatment, and to improve quality of life.

\section{Financial support. Not received.}

\section{Copyright}

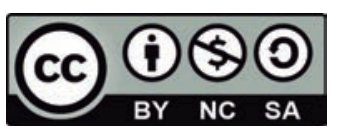

(C) 2021 Acta Gastroenterológica latinoamericana. This is an openaccess article released under the terms of the Creative Commons Attribution (CC BY-NC$S A$ 4.0) license, which allows non-commercial use, distribution, and reproduction, provided the original author and source are acknowledged.

Cite this article as: Toro-Monjaraz E, Peña-Vélez $R$, Carrillo-Quan MJ, et al. High-Resolution Manometry in the Diagnosis and Classification of Achalasia in Children. Acta Gastroenterol Latinoam. 2020;50(1):57-61. https:// doi.org/10.52787/ggus 4980

\section{References}

1. Franklin AL, Petrosyan M, Kane TD. Childhood achalasia: A comprehensive review of disease, diagnosis and therapeutic management. World J Gastrointest Endosc 2014; 6 (4): 105-111.

2. Lasso CE, Garrido JI, Gómez OD, Castillo AL, Granero R, Paredes RM. La acalasia en la infancia y la adolescencia un reto terapéutico. Cir Pediatr 2014; 27: 6-10.

3. Van Lennep M, van Wijk MP, Omari TIM, Benninga MA, Singendonk MMJ. Clinical management of pediatric achalasia. Expert Rev Gastroenterol Hepatol 2018; 12 (4): 391-404.

4. Pastor AC, Mills J, Marcon MA, Himidan S, Kim PC. A single centre 26-year experience with treatment of esophageal achalasia: is there an optimal method? J Pediatr Surg 2009; 44 (7): 1349-1354.

5. Eckardt VF, Köhne U, Junginger T, Westermeier T. Risk factors for diagnostic delay in achalasia. Dig Dis Sci. 1997; 42 (3): 580-585.

6. Kessing BF, Smout AJ, Bredenoord AJ. Clinical applications of esophageal impedance monitoring and high-resolution manometry. Curr Gastroenterol Rep 2012; 14 (3): 197-205.

7. Kahrilas PJ, Bredenoord AJ, Fox M, Gyawali CP, Roman S, Smout AJ, Pandolfino JE. The Chicago Classification of esophageal motility disorders, v3.0. Neurogastroenterol Motil 2015; 27 (2): 160-174.

8. Flández J, Monrroy H, Morales E, Cisternas D. Clasificación de Chicago para trastornos de la motilidad esofágica versión 3.0. Gastroenterol latinoam 2016; 27 (1): 51-61.

9. González-Rodríguez R, Ortiz-Olvera NX, González Martínez M, Flores-Calderón J. Achalasia in Pediatric Population: Use of High-Resolution Manometry in Children, Achalasia in Pediatric Population. J Gastrointest Dig Syst 5: 286.

10. Edeani F, Malik A, Kaul A. Characterization of Esophageal Motility Disorders in Children Presenting With Dysphagia Using High-Resolution Manometry. Curr Gastroenterol Rep 2017; 19 (3): 13.

11. Singendonk MMJ, Ferris LF, McCall L, Seiboth G, Lowe K, Moore D, Hammond P, Couper R, Abu-Assi R, Cock C, Benninga MA, van Wijk MP, Omari T. High-resolution esophageal manometry in pediatrics: Effect of esophageal length on diagnostic measures. Neurogastroenterol Motil 2020; 32 (1): e13721. 